Fractionation of lead $(\mathrm{Pb})$ in soil by isotopic dilution and sequential extraction.

N.R. Atkinson, ${ }^{1}$ E.H. Bailey, ${ }^{1}$ A.M. Tye ${ }^{2}$, N. Breward, ${ }^{2}$ S.D. Young $^{1 *}$

${ }^{1}$ Division of Agriculture and Environmental Sciences, School of Biosciences, University of Nottingham, University Park, Nottingham, Nottinghamshire, NG7 2RD, UK. ${ }^{2}$ British Geological Survey, Keyworth, Nottingham, NG12 5GG, UK

* Corresponding author: Tel: +44 (0)115 9516256; Email: scott.young@nottingham.ac.uk 


\section{Environmental context}

The chemical reactivity of lead in soil is difficult to assess and depends on both soil conditions and the origins of the lead. This paper tests the combined application of lead isotopic techniques and chemical extraction to our understanding of lead fractionation in soils. Possibly against expectation, it appears that the 'reactivity' of lead can be high and yet there is tentative evidence that the original source of the metal affects its fractionation in soil, even after long contact times. 


\section{Abstract}

'Reactivity' or 'lability' of lead is difficult to measure using traditional methods. We investigated the use of isotopic dilution with ${ }^{204} \mathrm{~Pb}$ to determine metal reactivity in four soils historically contaminated with contrasting sources of $\mathrm{Pb}$, including (i) petrol-derived $\mathrm{Pb}$, (ii) $\mathrm{Pb} / \mathrm{Zn}$ mine-spoil, (iii) long-term sewage sludge application and (iv) $\mathrm{C} 19^{\text {th }}$ urban waste disposal; total soil $\mathrm{Pb}$ concentrations ranged from $217-13600 \mathrm{mg} \mathrm{kg}^{-1}$. A post-spike equilibration period of three days and $5.0 \times 10^{-4} \mathrm{M}$ EDTA electrolyte provided reasonably robust conditions for measuring isotopically-exchangeable $\mathrm{Pb}$ although in acidic organic soils a dilute $\mathrm{Ca}\left(\mathrm{NO}_{3}\right)_{2}$ electrolyte may be better to avoid mobilisation of 'non-labile' $\mathrm{Pb}$. Results showed that the reactive pool of soil $\mathrm{Pb}$ is often larger than may be intuitively expected but varies with the original $\mathrm{Pb}$ source. A comparison of isotopic exchangeability with the results of a sequential extraction procedure showed that (isotopically) 'non-labile' $\mathrm{Pb}$ may be broadly equated with 'residual' $\mathrm{Pb}$ in organic soils. However, in mineral soils the 'calcareous' and 'oxide-bound' $\mathrm{Pb}$ fractions included non-labile forms of $\mathrm{Pb}$. De-coupling the isotopic signature of labile and nonlabile $\mathrm{Pb}$ pools suggested that, despite prolonged contact with soil, differences between the lability of the original contaminant and the native soil $\mathrm{Pb}$ may remain.

Keywords: Lead; contamination; stable isotope dilution; lability; E value; source apportionment. 
Human activities have resulted in the accumulation of lead in the biosphere, through processes such as smelting of lead ore, atmospheric deposition from leaded petrol, coal and oil combustion, and production of steel and non-ferrous metals. ${ }^{[1,2,3]}$ Sequential extraction of soils have shown that $\mathrm{Pb}$ is often associated with $\mathrm{Fe}$ and $\mathrm{Mn}$ oxide minerals and organic / sulphide fractions. ${ }^{[4,5,6]}$ For example, Strawn et al., ${ }^{[7]}$ showed that $\mathrm{Pb}$ was associated with Mn oxides and poorly crystallised $\mathrm{Fe}$ oxides, using electron microprobe and X-ray diffraction analyses of contaminated wetland soils. However, Lang \& Kaupenjohann ${ }^{[8]}$ suggested that $\mathrm{Pb}$ phosphates, especially pyromorphites, are the most stable $\mathrm{Pb}$-containing minerals under a wide range of conditions, and so would be expected to be present in $\mathrm{Pb}$-contaminated soils.

Current UK regulations relating to $\mathrm{Pb}$ contamination are based on total lead concentration in soil. It is considered that $\mathrm{Pb}$ is relatively unavailable for plant uptake, and the major pathway of human risk is direct ingestion of soil and indoor dust. ${ }^{[9]}$ The 'Soil Guideline Value' (SGV) adopted by the Environment Agency in $2002^{[9]}$ ( $450 \mathrm{mg} \mathrm{kg}^{-1}$ for residences and allotments) is based on work by the Society for Environmental Geochemistry and Health ${ }^{[10]}$ suggesting an empirical relationship between the (total) concentration of $\mathrm{Pb}$ in soil and in blood. However the reactivity, or 'lability', of soil lead may affect bioavailability and so total lead content may not always be the best means of assessing risk. ${ }^{[11]}$ In addition, as lability reflects the ability of soilborne metals to transfer between the soil solid and solution phases, it will have implications both for plant uptake and movement of $\mathrm{Pb}$. Lability can be operationally measured as the fraction of metal which is 'isotopically exchangeable' in a soil suspension, the 'E-value'. ${ }^{[12]}$ Early studies used radio-isotopes with the advantage that a small spike is easily measurable without altering the pre-existing solid-solution equilibrium. ${ }^{[12,13,14,15]}$ Unfortunately, the lack of suitable radioisotopes for $\mathrm{Pb}$ and $\mathrm{Cu}$ means that there is little data on the lability of these important metals. ${ }^{[16]}$ However, in recent years, with wider access to inductively coupled plasma-mass spectrometry (ICP-MS) technology, the use of stable isotopes has become more common. The stable isotope ${ }^{65} \mathrm{Cu}$ was used by Nolan et al., ${ }^{[14]}$ to measure the lability of $\mathrm{Cu}$ in soil and isotopically exchangeable $\mathrm{Pb}$ has also been determined. ${ }^{[11,16,17]}$ Measurements of isotopically exchangeable $\mathrm{Pb}$ in soil have shown surprisingly high proportions of labile $\mathrm{Pb}$. Tongtavee et al., ${ }^{[1]}$ reported that an average of $58 \%$ (40.4 - 64.9\%) of total soil $\mathrm{Pb}$ was labile using a ${ }^{207} \mathrm{~Pb}$ spike $(22.1 \%$ natural abundance). Degryse et al., ${ }^{[16]}$ used a ${ }^{208} \mathrm{~Pb}$ spike (52.4\% natural abundance) and found that an average of $58 \%(45-78 \%) \mathrm{Pb}$ in historically contaminated soils was labile. These studies suggest that the lability of $\mathrm{Pb}$ in soil may be greater than was previously predicted ${ }^{[18]}$ or 
generally assumed from the relative strength of $\mathrm{Pb}$ sorption and the suggestion that $\mathrm{Pb}$ forms discrete solid phases in soil, such as chloropyromorphite. ${ }^{[19]}$

The primary objective of this research was to develop a $\mathrm{Pb}$ stable isotope dilution method, using ${ }^{204} \mathrm{~Pb}$, and compare this approach with a chemical extractent (EDTA) commonly used to measure 'available' soil metal. The low natural abundance of ${ }^{204} \mathrm{~Pb}(1.4 \%)$ allows a small amount of $\mathrm{Pb}$ to be used as a tracer, which minimises any impact of the spike on the soil $\mathrm{Pb}$ equilibrium. $\mathrm{We}$ used four soils with markedly different $\mathrm{Pb}$ concentrations and sources of contamination to provide a range of $\mathrm{Pb}$ solubility and isotopic exchangeability. The effect of suspending electrolyte was also investigated as part of the method development. The modified Tessier sequential extraction scheme (SEP) presented by Li \& Thornton, ${ }^{[20]}$ was used to determine whether isotopic exchangeability could be equated with combinations of $\mathrm{Pb}$ fractions determined by the SEP. Finally, an attempt was made to de-couple the lability of two individual $\mathrm{Pb}$ sources in the soils, assumed to be $\mathrm{UK}$ petrol-Pb and native (English) $\mathrm{Pb}$ ores (including coal). The objective was to determine the extent to which $\mathrm{Pb}$ from individual sources retains reactive characteristics which reflect its origins, despite long-term contact with soil.

\section{Experimental}

\section{Soil sampling}

Soil was collected from four sites in England, selected to represent a range of $\mathrm{Pb}$ contamination histories and metal concentrations. Sample locations included: (i) an arable fenland topsoil with high $\mathrm{Pb}, \mathrm{Zn}$ and $\mathrm{Cu}$ concentrations from urban waste disposal in the late $\mathrm{C} 19^{\text {th }}$ and early $\mathrm{C} 20^{\text {th }},{ }^{[21]}$ (ii) an uncultivated grassland site contaminated with $\mathrm{Pb} / \mathrm{Zn}$ mine-spoil, (iii) a sewage sludge processing farm managed by a major water company and (iv) a grassed roadside location.

The arable fenland near Manchester, (Lancashire, 53 $28^{\prime} 34^{\prime \prime} \mathrm{N}, 2^{\circ} 24^{\prime} 11^{\prime \prime} \mathrm{W}$; elev. $26 \mathrm{~m}$ ) was a moorland which was reclaimed for arable agriculture in the $19^{\text {th }}$ Century, during which large quantities of urban waste from Manchester was incorporated into the soil (Phillips, 1980). The minespoil site (Derbyshire, 53 09'07” N, $1^{\circ} 36^{\prime} 52^{\prime}$ ' W; elev. $139 \mathrm{~m}$ ) was directly contaminated by $\mathrm{Pb} / \mathrm{Zn}$ Minespoil, mined in the region since the $17^{\text {th }}$ century, particularly between 1859 and 1939. ${ }^{[23]}$ The sewage processing farm (Nottinghamshire, 52 $57^{\circ} 33^{\prime \prime} \mathrm{N}, 1^{\circ} 02$ ' 49" W; elev. 20 $\mathrm{m}$ ) has been in use for over 100 years, and is currently run by a major UK water company, under licence from DEFRA, for production of animal fodder. The roadside location (Leicestershire, 
$52^{\circ} 49^{\prime} 35^{\prime \prime} \mathrm{N}, 1^{\circ} 16^{\prime} 19^{\prime \prime} \mathrm{W}$; elev $37 \mathrm{~m}$ ) has a high traffic density but has a low natural soil $\mathrm{Pb}$ content so that the majority of the topsoil $\mathrm{Pb}$ was expected to be petrol-derived.

\section{Soil characterisation}

Topsoil samples $(0-20 \mathrm{~cm})$ were collected at all sites, air-dried and sieved to $<2 \mathrm{~mm}$. Organic matter content was estimated by loss on ignition at $550^{\circ} \mathrm{C}$ for 7 hours. Soil $\mathrm{pH}$ value was measured in deionised water suspension (1:2.5 soil:solution ratio) after shaking for 30 minutes. Subsamples of the $<2 \mathrm{~mm}$ sieved soil were agate ball-milled (Retsch, PM400) prior to acid digestion of $200 \mathrm{mg}$ quantities in PTFE vessels with $2.5 \mathrm{ml} \mathrm{HF}, 2 \mathrm{ml} \mathrm{HNO} 3$ and $1 \mathrm{ml} \mathrm{HClO}_{4}$. Total soil metal concentrations were determined by ICP-MS (Thermo-Fisher Scientific XSeries $^{\mathrm{II}}$ ); quality control was assured by analysis of NIST-SRM 2711 (Montana soil). Available phosphate was determined using extraction by Olsen's method and colorimetric assay; ${ }^{[24]}$ total soil phosphate was measured by ICP-AES on the digested soils.

Measurement of $\mathrm{Pb}$ isotopic abundance

Lead isotope ratios in soil digests were measured by quadrupole ICP-MS (Thermo-Fisher XSeries $^{\mathrm{II}}$ ) operating in standard mode. Isotope ratios were measured with a dwell time of $2.5 \mathrm{~ms}$ and quadrupole settle time of $1000 \mu \mathrm{S}$ to minimise the effects of plasma noise; up to $15 \times 100$ sweeps of the quadrupole were used for each sample. Solutions of the $\mathrm{Pb}$ isotope standard NIST-981 (typically 8, 16, 24, 32 and $40 \mu \mathrm{g} \mathrm{L}^{-1}$ ) were used to determine correction factors for the detector 'dead time' and for mass bias (K-factors) during analysis. ${ }^{[25]}$ Only data measured in true pulse-counting mode were used to determine isotopic abundances; data were rejected if the detector 'tripped' to an analogue signal.

Isotopically exchangeable $\mathrm{Pb}$ (E-value)

The concentration of labile $\mathrm{Pb}$ was measured on subsamples of $2 \mathrm{~g}$ soil pre-equilibrated with 30 $\mathrm{ml}$ of electrolyte on a rotary shaker for 3 days. Six replicates of each sample were assayed: three were used to measure natural $\mathrm{Pb}$ isotopic abundances, and three were spiked after the initial equilibration period with $400 \mu \mathrm{L}$ of ${ }^{204} \mathrm{~Pb}$ solution $\left(99.7 \%{ }^{204} \mathrm{~Pb}\right.$, Oak Ridge National Laboratories). The spike concentration was chosen to double the natural ${ }^{204} \mathrm{~Pb}$ content of the most contaminated soil, and equated to $23 \mu \mathrm{g}{ }^{204} \mathrm{~Pb}$ added to all samples. All suspensions were then equilibrated, for variable periods, before centrifuging ( $2200 \mathrm{~g}$ for 15 minutes) and filtering the supernatant $(<0.2 \mu \mathrm{m}$ cellulose acetate filters). The resulting solutions were analysed by 
ICP-MS to determine isotopic abundances (IA) of the four Pb isotopes ${ }^{204} \mathrm{~Pb},{ }^{206} \mathrm{~Pb},{ }^{207} \mathrm{~Pb}$ and ${ }^{208} \mathrm{~Pb}$.

Seven suspending electrolytes with increasing extraction strength were tested, including $0.01 \mathrm{M}$ $\mathrm{Ca}\left(\mathrm{NO}_{3}\right)_{2}$ and a range of EDTA concentrations including $(0.0337,0.114,0.384,1.3,4.38$ and 14.2; all $\times 10^{-3} \mathrm{M}$ ). These were selected to optimise the competing aims of dissolving sufficient $\mathrm{Pb}$ to provide an analytically robust assay and rapid isotopic equilibration, but without mobilising (otherwise) non-labile soil $\mathrm{Pb}$. The labile pool of $\mathrm{Pb}$ (E value, $\mathrm{mg} \mathrm{kg}^{-1}$ ) was calculated from Equation (1).

E value $=\left(\frac{\mathrm{M}_{\text {Pb soil }}}{W}\right)\left(\frac{\mathrm{C}_{\text {spike }} \mathrm{V}_{\text {spike }}}{\mathrm{M}_{\mathrm{Pb}_{\text {spike }}}}\right) \frac{\left({ }^{204} \mathrm{IA}_{\text {spike }}-{ }^{208} \mathrm{IA}_{\text {spike }} \mathrm{R}_{\mathrm{SS}}\right)}{\left({ }^{208} \mathrm{IA}_{\text {soil }} \mathrm{R}_{\mathrm{SS}}-{ }^{204} \mathrm{IA}_{\text {soil }}\right)}$

$\mathrm{M}_{\mathrm{Pb}}$ is the average atomic mass of $\mathrm{Pb}, \mathrm{C}$ is gravimetric $\mathrm{Pb}$ concentration $\left(\mathrm{mg} \mathrm{L}^{-1}\right), \mathrm{V}$ is the volume of added spike (L), W is the weight of soil $(\mathrm{kg})$, IA denotes isotopic abundance of a particular isotope in the spike or soil and $\mathrm{R}_{\mathrm{SS}}$ is the ratio of isotopic abundances for ${ }^{204} \mathrm{~Pb}$ to ${ }^{208} \mathrm{~Pb}$ calculated for the spiked soil supernatant.

The natural isotopic composition of the labile and non-labile pools was also determined in an attempt to identify the source of labile, and non-labile, forms of $\mathrm{Pb}$ in each soil. Data are presented as the isotopic ratio ${ }^{206} \mathrm{~Pb} /{ }^{207} \mathrm{~Pb}$ plotted against ${ }^{206} \mathrm{~Pb} /{ }^{208} \mathrm{~Pb}$ to aid identification of the source of the $\mathrm{Pb}$ in soil. ${ }^{[2,26]}$ To characterise $\mathrm{Pb}$ in the whole soil, and the labile pool, ratios of isotopic abundances were measured in the acid digest and in the electrolyte used to determine Evalue, respectively. Isotopic ratios in the non-labile $\mathrm{Pb}$ pool were calculated from consideration of mass balance and the measured proportion of isotopically exchangeable $\mathrm{Pb}$. Thus, for ${ }^{206} \mathrm{~Pb}$ :

$$
{ }^{206} \mathrm{IA}_{\mathrm{NL}}=\frac{{ }^{206} \mathrm{IA}_{\text {soil }}-\left({ }^{206} \mathrm{IA}_{\mathrm{L}} \times \mathrm{P}_{\mathrm{L}}\right)}{\left(1-\mathrm{P}_{\mathrm{L}}\right)}
$$

where ${ }^{206}$ IA refers to the isotopic abundance (of ${ }^{206} \mathrm{~Pb}$ ) in the labile (L) and non-labile (NL) pools or the whole soil and $\mathrm{P}_{\mathrm{L}}$ is the molar proportion of labile $\mathrm{Pb}$ in the soil.

Sequential extraction of lead 
An adaptation of the Tessier method ${ }^{[20]}$ was used in this study as it is a robust scheme that has been widely applied; a summary is shown in Table 1.

Results and Discussion

Soil characteristics and origins of soil $\mathrm{Pb}$.

Characteristics of the four soils are shown in Table 2. The Arable Fenland soil had a large organic matter content (61.5\%) and low $\mathrm{pH}(5.28)$, whereas the other soils had circum-neutral to alkaline $\mathrm{pH}$ values $(6.24-7.90)$ and lower organic matter contents. The Sewage farm soil had a very high available, and total, phosphate content. The Roadside and Minespoil soils were similar in terms of $\mathrm{pH}$, organic matter and phosphate content but showed the greatest contrast in $\mathrm{Pb}$ concentration. The total $\mathrm{Pb}$ concentrations of the four soils ranged from $217 \mathrm{mg} \mathrm{kg}^{-1}$ (Roadside) to $13600 \mathrm{mg} \mathrm{kg}^{-1}$ (Minespoil).

Figure 1 shows the $\mathrm{Pb}$ isotopic ratios ${ }^{206} \mathrm{~Pb} /{ }^{207} \mathrm{~Pb}$ and ${ }^{206} \mathrm{~Pb} /{ }^{208} \mathrm{~Pb}$ measured in the acid digests of the four soils with corresponding data for significant reference materials, including $\mathrm{Pb}$ from 'petrol-derived', UK coal and UK Pb-ore sources (Chenery, S., British Geological Survey, pers. comm..). The four soils covered a range of isotope ratios, suggesting that each soil contained a distinctive combination of $\mathrm{Pb}$ sources. As expected, the Minespoil soil was within the range of $\mathrm{UK} \mathrm{Pb}$ ore. The Arable Fenland soil was also very close to the $\mathrm{Pb}$ ore signature but, considering its urban origins, should also be affected by contributions from $\mathrm{UK}$ coal and petrol-derived $\mathrm{Pb}$. A major constituent of the solid waste input to the Chat Moss site was coal ash from the city of Manchester. The Sewage farm soil was characterised by a more mixed $\mathrm{Pb}$ isotopic signature. Soil at this site probably contains more recent urban inputs with less coal ash and more run-off material from roads which would explain the greater contribution from petrol-derived $\mathrm{Pb}$. As expected, the Roadside soil showed the greatest contribution from petrol-derived $\mathrm{Pb}$. However, the total $\mathrm{Pb}$ concentration in this soil was relatively small and so $\mathrm{Pb}$ from the parent material must also feature in the overall isotopic signature. The location of the roadside soil is just south of Derbyshire (UK) and so the $\mathrm{Pb}$ isotopic signature in the parent material may be close to that of Derbyshire $\mathrm{Pb}$ ore.

Measurement of $\mathrm{Pb}$ E-value: optimising the suspending electrolyte

The purpose of this experiment was to determine the effect of electrolyte composition on $\mathrm{Pb}$ solubilisation and lability measurements. Increasing EDTA concentration increased the apparent 
E-value of all four soils (Fig. 2), clearly demonstrating that non-labile $\mathrm{Pb}$ is mobilised by the chelating reagent. However, in three of the four soils the apparent E-value was virtually constant below approximately $5 \times 10^{-4} \mathrm{M}$ EDTA, suggesting that this concentration may provide a viable suspending electrolyte. Only the Arable Fenland soil demonstrated a continuous increase in apparent E-value with EDTA across the full range of concentrations tested.

Using natural stable isotopes in isotopic dilution studies presents one significant disadvantage compared to the use of radioisotopes. In the presence of very large reactive metal pools the spike enrichment above background becomes too small to determine accurately. The impact of this error, at the level of isotopic spike used in this study may be illustrated by arbitrarily imposing systematic errors $( \pm 1 \%$ and $10 \%)$ on the measured ${ }^{204} \mathrm{~Pb}$ isotopic abundances. As seen in Figure 2, the error associated with calculation of E-value increased considerably as the reactive pool of $\mathrm{Pb}$ mobilised by EDTA increased and the difference in isotopic abundance between background and spiked samples diminished. This underlines the importance of ensuring that the level of spike applied to individual soils produces a significant increase in isotopic abundance in the equilibrated solution.

Thus the optimum electrolyte should solubilise sufficient $\mathrm{Pb}$ to be analytically robust, and allow rapid isotopic equilibration, without bringing non-labile $\mathrm{Pb}$ into solution. The E-values for 0.01 $\mathrm{M} \mathrm{Ca}\left(\mathrm{NO}_{3}\right)_{2}$ were very close to those for the lowest two EDTA concentrations $(<0.0005 \mathrm{M})$ in the Arable Fenland and Roadside soils, giving \% E-values of $37 \%$ and $34 \%$ respectively. However, suspension in $\mathrm{Ca}\left(\mathrm{NO}_{3}\right)_{2}$ produced larger \% E-values for the Sewage Farm $(30 \%)$ and Minespoil soils (68\%). The use of a neutral salt as suspending electrolyte does not risk mobilisation of non-labile $\mathrm{Pb}$. However, a possible advantage in using 0.0005 M EDTA over $0.01 \mathrm{M} \mathrm{Ca}\left(\mathrm{NO}_{3}\right)_{2}$ lies in the lower reliability of isotopic analysis at extremely low $\mathrm{Pb}$ concentrations in supernatant solutions where samples are more vulnerable to the effects of $\mathrm{Pb}$ contamination and instrumental limitations. Solution concentrations of $\mathrm{Pb}$ in $0.0005 \mathrm{M}$ EDTA were typically two orders of magnitude greater than in $0.01 \mathrm{M} \mathrm{Ca}\left(\mathrm{NO}_{3}\right)_{2}$ suspensions. Thus, for the Sewage farm soil in particular, the E-value measured using $\mathrm{Ca}\left(\mathrm{NO}_{3}\right)_{2}$ as the suspending electrolyte was highly variable and was judged analytically unreliable. By contrast, a neutral salt electrolyte is probably the more appropriate choice for the Arable Fenland soil which did not tend to an asymptotic E-value as EDTA concentration was reduced.

Measurement of labile lead in soils contaminated from different sources 
Table 3 shows the (\%)E-values of the Arable Fenland, Minespoil, Sewage farm and Roadside soils measured using an electrolyte concentration of 0.0005 M EDTA and an isotopic spike equilibration time of 3 days. The Arable Fenland soil had a varied contamination source of municipal waste, and was characterised by an exceptionally high organic matter content (61.5\%) originating partly from waste disposal (e.g. $19^{\text {th }}$ Century night soil) but mainly from the underlying peat into which the waste materials were incorporated. It is likely that the high organic matter content and low $\mathrm{pH}$ values (Table 2) were the principal reasons for the high lability of $\mathrm{Pb}$ in this soil (65\%). It is well known that $\mathrm{Pb}$ strongly binds to organic matter, ${ }^{[27,28 \text {, }}$ ${ }^{29]}$ but sorption on humus is unlikely to lead to physical occlusion as would be expected in $\mathrm{Pb}$ compounds such as chloropyromorphite, or within the solid matrix of Fe hydrous oxides.

By contrast, soil from the sewage sludge disposal site showed the lowest lability of all four soils $(13.5 \%)$. This was perhaps surprising because the organic matter content of the site was large. However this site also had extremely large available (453 $\left.\mathrm{mg} \mathrm{kg}^{-1}\right)$ and total $\left(9540 \mathrm{mg} \mathrm{kg}^{-1}\right)$ phosphate contents (Table 2) suggesting formation of insoluble $\mathrm{Pb}$-phosphates such as chloropyromorphite $\left(\mathrm{Pb}_{5}\left(\mathrm{PO}_{4}\right)_{3} \mathrm{Cl}\right){ }^{[8,27,28]}$

The $\mathrm{Pb}$ lability measured in the Minespoil soil was most likely to be affected by the original form of the contamination. Lead mineralisation in the Derbyshire region is in the form of galena $(\mathrm{PbS})$, cerrusite $\left(\mathrm{PbCO}_{3}\right)$ and pyromorphites, ${ }^{[20]}$ which can all constitute stable forms of $\mathrm{Pb}$ depending on soil conditions. ${ }^{[27]}$ Through sequential extractions, Li \& Thornton $^{[20]}$ showed that $\mathrm{Pb}$ in soils from old Derbyshire mining sites is predominantly associated with a carbonate phase, and that thermodynamic predictions identify cerrusite as the dominant $\mathrm{Pb}$ mineral. Nevertheless, despite an extremely large $\mathrm{Pb}$ content, calcareous nature and high $\mathrm{pH}$ the lability of $\mathrm{Pb}$ in the Minespoil soil was surprisingly high, at $30 \%$, suggesting that substantial re-adsorption on humus and other colloidal phases had occurred.

The isotopic exchangeability of $\mathrm{Pb}$ in the Roadside soil was $52 \%$ of the total $\mathrm{Pb}$ content. For this soil, the original form of the $\mathrm{Pb}$ contamination was possibly less important in determining lability. Lead oxide particles emitted from car exhausts would be expected to dissolve in soil with adsorption of $\mathrm{Pb}$ on to $\mathrm{Fe}$ hydrous oxides and humus; other studies have shown that petrolderived $\mathrm{Pb}$ has a strong affinity for Fe oxides in Roadside soils. ${ }^{[30]}$

The results obtained here may be compared with those of Degryse et al., ${ }^{[16]}$ who recorded a range of $\mathrm{Pb}$ lability from 45 to $78 \%$ in field contaminated soils using a ${ }^{208} \mathrm{~Pb}$ spike. Tongtavee et al., ${ }^{[11]}$ also recorded lability of $57 \%$ in smelter contaminated soils using a ${ }^{207} \mathrm{~Pb}$ spike. These 
results, and our own for the roadside and Arable Fenland soils, suggest that $\mathrm{Pb}$ is more labile than might be expected from a general understanding of $\mathrm{Pb}$ solubility in soils - especially in the absence of specific conditions likely to either sustain or promote fixed forms, as found in the minespoil soil and at the sewage disposal site respectively.

Fractionation of lead as measured by sequential extraction

The fractionation of $\mathrm{Pb}$ varied between the four soils (Table 4), although in all cases there was a very low proportion of $\mathrm{Pb}$ in the exchangeable fraction, as expected. ${ }^{[11,16]}$ In the Sewage farm soil, $98 \%$ of $\mathrm{Pb}$ was apparently in the residual fraction. This unusual result may again reflect the extremely high phosphate content of this soil (Table 2); Pb-phosphates would not be expected to dissolve in the first four fractions of the sequential extraction scheme. In the Arable Fenland soil, the dominant fraction hosting $\mathrm{Pb}$ was humus, with $41 \%$ of the total soil $\mathrm{Pb}$ content; this was followed by the residual fraction (28\%) and the Fe/Mn oxide fraction (23\%). This corresponds with the known behaviour of $\mathrm{Pb}$ in acidic organic soils, such as wetlands. ${ }^{[31]}$ In fact it is likely that much of the $\mathrm{Pb}$ extracted in F1 - F3 was also organically bound as it is unlikely that carbonate forms existed in such an acidic soil (pH 5.28). In the Roadside soil, the fractionation was dominated by the Fe/Mn oxide fraction (57\%). Iron and manganese oxides normally provide the most important adsorption surface for $\mathrm{Pb}$, particularly at the high $\mathrm{pH}$ value $(\mathrm{pH} 7.90)$ of the roadside soil. ${ }^{[20,32,33]}$ The residual $(21 \%)$ and organic $(15 \%)$ fractions were the next most important fractions in this soil. The Minespoil soil had similar fractionation to the Roadside soil, although the $\mathrm{Pb}$ was more evenly distributed between the Fe/Mn oxide, organic and residual fractions. The soil also had the highest proportion of $\mathrm{Pb}$ in the carbonate fraction (19\%) suggesting that the original $\mathrm{Pb} / \mathrm{Zn}$-sulphide minerals had weathered to carbonate phases.

\section{Comparison of $\mathrm{Pb}$ fractionation and lability}

Figure 3 compares the SEP fractionation with the isotopically exchangeable $\mathrm{Pb}$ in the four soils. In the Arable Fenland soil, there was good agreement between the proportion of isotopically exchangeable $\mathrm{Pb}(65 \%)$ and the proportion of lead (72\%) in the combined non-residual fractions of the sequential extraction procedure ( $\left.\mathrm{SEP}_{\text {react }}\right)$. This might suggest a fairly clear distinction between immediately reactive $\mathrm{Pb}$, bound mainly to organic matter, and $\mathrm{Pb}$ in primary mineral form. The Sewage farm soil also showed qualitative agreement in that both the $\mathrm{SEP}_{\text {react }}$ and the isotopically exchangeable fractions were extremely small. However, for the other two mineral soils there was no obvious correspondence and the $\mathrm{SEP}_{\text {react }}$ greatly exceeded the isotopically exchangeable $\mathrm{Pb}$ pool. Differences ( $\mathrm{SEP}_{\text {react }}-\mathrm{E}$-value) were $27 \%$ and $44 \%$ of total soil $\mathrm{Pb}$ for 
the Roadside and Minespoil soils respectively. These values effectively correspond to the proportion of soil $\mathrm{Pb}$ that is accessible to the SEP fractionation scheme but is occluded within oxide and carbonate minerals, or bound to humus in kinetically constrained forms, and so does not immediately mix with isotopic labels.

Thus combining sequential extraction and stable isotope dilution may generate unique information on the binding of soil metals, by further fractionating $\mathrm{SEP}_{\text {react }}$ metal into 'labile' and 'non-labile' forms. Furthermore, the difference between 'non-labile' and 'residual' may correspond to the distinction suggested by Degryse et al., ${ }^{[16]}$ between 'non-labile' and truly 'inert'. Nevertheless, it is clear that only one soil (Sewage Farm) demonstrated a convincing distinction between reactive and non-reactive $\mathrm{Pb}$.

Isotopic signature of labile and non-labile $\mathrm{Pb}$ pools

Figure 4 shows the isotopic signature of the labile and non-labile $\mathrm{Pb}$ fractions for each soil presented on the same mixing line shown in Figure 1 (equation 2). For all soils the isotopic ratios of the labile and non-labile fractions were significantly different (paired T-test). However, in no case were the labile or non-labile fractions exclusively attributable to a single $\mathrm{Pb}$ source. This suggests considerable, but incomplete, mixing of sources between the two fractions defined by isotopic exchange as a result of prolonged soil contact time. For the Fenland and Minespoil soils the non-labile fraction was strongly associated with the isotopic signature of English $\mathrm{Pb}$ ores and/or coal while the labile fraction was displaced slightly towards petrol-derived $\mathrm{Pb}$. The roadside soil showed this trend much more clearly, with labile $\mathrm{Pb}$ positioned close to petrol- $\mathrm{Pb}$; the non-labile $\mathrm{Pb}$ was closer to native $\mathrm{Pb}$-ore which would fit with the expected signature of the soil parent material. However, the non-labile $\mathrm{Pb}$ in the Roadside soil was still considerably displaced from the $\mathrm{Pb}$ ore on the mixing line, suggesting that fixed petrol-derived $\mathrm{Pb}$ also contributed substantially to the non-labile pool. The Sewage Farm soil presented a contrasting distribution with the labile $\mathrm{Pb}$ closer to the 'native' soil source. A possible explanation for this is that the majority non-labile fraction (87\%) was probably formed by reaction between $\mathrm{Pb}$ and phosphate within the sewage sludge which is likely to feature a strong petrol- $\mathrm{Pb}$ signature whereas the native soil $\mathrm{Pb}$ in the Trent valley will be close to the English $\mathrm{Pb}$-ore in origin. The original 'lability' of the native $\mathrm{Pb}$ would be higher than the current Sewage Farm soil and this characteristic appears to survive in part given the distribution of the labile and non-labile forms on the isotopic mixing line. It should be stressed that the current study is a preliminary attempt to investigate the lability of different soil $\mathrm{Pb}$ sources and although the random error in calculating the isotopic signature of the two fractions was small we cannot rule out systematic 
variance which may have distorted the results, notwithstanding the use of a CRM (NIST 981) to correct raw data. Indeed, it appears surprising to see any difference between the isotopic signatures of labile and non-labile $\mathrm{Pb}$ given the extended soil-Pb contact times involved. Again, however, this finding appears to support a distinction between a 'non-labile' pool and a truly 'inert' metal phase.

A stable isotope dilution method to determine reactive soil $\mathrm{Pb}$ has been developed using ${ }^{204} \mathrm{~Pb}$ and tested on four soils with contrasting histories of $\mathrm{Pb}$ contamination. To achieve sufficient $\mathrm{Pb}$ solubilisation for analytical purposes without dissolving non-labile $\mathrm{Pb}$, the most effective suspending electrolyte was $5 \times 10^{-4} \mathrm{M}$ EDTA with a post-spike equilibration time of 2-3 days. However, in acidic organic soils addition of EDTA produced a continuous increase in apparent E-value. The lability of $\mathrm{Pb}$ in the four soils ranged from 13\% (Sewage farm) to $65 \%$ (Arable Fenland) of total soil $\mathrm{Pb}$ and could be qualitatively explained from the original contaminant source and current soil conditions. A comparison with a sequential extraction procedure (SEP) showed that in the two highly organic soils (Sewage farm and Fenland) there was reasonable correspondence between the E-value and the summation of the SEP reactive fractions ( $\left.\mathrm{SEP}_{\text {react }}\right)$. However, in the mineral soils, $\mathrm{SEP}_{\text {react }}$ exceeded the E-value indicating the greater presence of occluded non-labile forms of $\mathrm{Pb}$ which nevertheless remained distinct from inert forms in the 'residual' fraction of the SEP. Examination of the isotopic composition of the labile and nonlabile pools indicated that native soil $\mathrm{Pb}$ and contaminant sources retain some degree of distinction despite prolonged contact. This may be a surprising result but it appears to be valid from the limited data available. Differences in the isotopic signature of labile and non-labile pools appear to fit 'expected' trends given the history of contaminant addition to the soils. Overall, the study suggests that there is considerable scope for characterising soil $\mathrm{Pb}$ from combined determination of SEP fractionation, E-values and natural isotopic abundances. 


\section{Acknowledgments}

The authors wish to thank the British Geological Survey (BGS) and the University of

Nottingham for providing research funding. Sincere thanks also go to Mr. J Stringer, land owner of the Arable Fenland site and Dr Simon Chenery (BGS) for Pb isotopic data of reference materials. 


\section{References}

[1]. R.M. Semlami, J-B. Dessogne, F. Monna, J. Bolte, S. Azimi, N Navarro, L. Denaix, M. Loubet, C. Chateau, F. van Oort, Modelling lead input and output in soils using lead isotope geochemistry. Environmental Science and Technology, 2004, 38, 1513-1521.

[2]. D. Weiss, W. Shotyk, P.G. Appleby, J.D. Kramers, A. Cheburkin, Atmospheric Pb deposition since the industrial revolution recorded by five Swiss peat profiles: Enrichment factors, fluxes, isotopic composition and sources. Environmental Science and Technology. 1999a, 33, 13401352.

[3]. D. Weiss, W. Shotyk, J.D. Kramers, M. Gloor, Sphagnum mosses as archives of recent and past atmospheric lead deposition in Switzerland. Atmospheric Environment, 1999b, 33, 3751-3763.

[4]. R. Burt, M.A. Wilson, T.J. Keck, B.D. Dougherty, D.E. Strom, J.A. Lindahl, Trace element speciation in selected smelter-contaminated soils in Anaconda and Deer Lodge Valley, Montana, USA. Advances in Environmental Research, 2003 8, 51-67.

[5]. G. Morin, J.D. Ostergren, F. Juillot, F., P. Ildefonse, G. Calas, G.E. Brown Jr, XAFS determination of the chemical form of lead in smelter-contaminated soils and mine tailings: importance of adsorption processes. American Mineralogist, 1999, 84, 420-434.

[6]. C.A. Wilson, M.S. Cresser, D.A. Davidson, Sequential element extraction of soils from abandoned farms: an investigation into the partitioning of anthropogenic element inputs from historic land use. Journal of Environmental Monitoring, 2006, 8, 439-444.

[7]. D.G. Strawn, P. Hickey, A. Knudsen, L. Baker, Geochemistry of lead contaminated wetland soils amended with phosphorus. Environmental Geology, 2007, 51, 109-122.

[8]. F. Lang, M. Kaupenjohann, Effect of dissolved organic matter on the precipitation and mobility of the lead compound chloropyromorphite in solution. European Journal of Soil Science, 2003, 54, $139-147$.

[9]. Environment Agency, Soil Guideline Values for lead contamination. 2002. Environment Agency R\&D Dissemination Centre, Swindon. 
[10]. SEGH Lead in Soil: Recommended Guidelines, 1993. Wixson BG and Davies BE eds, Society for Environmental Geochemistry and Health, Science Reviews.

[11]. N. Tongtavee, J. Shiowatana, R.G. McLaren, C.W. Gray, Assessment of lead availability in contaminated soil using isotope dilution techniques. Science of the Total Environment, 2005, 348, 244-256.

[12]. S.D. Young, A.M. Tye, A. Carstensen, L. Resende, N. Crout, Methods for determining labile cadmium and zinc in soil. European Journal of Soil Science, 2000, 51, 129-136.

[13]. D. Hammer, C. Keller, M.J. McLaughlin, R. Hamon, Fixation of metals in soil constituents and potential remobilisation by hyperaccumulating and non-hyperaccumulating plants: Results from an isotopic dilution study. Environmental Pollution, 2006, 143, 407-415.

[14]. A.L. Nolan, Y. Ma, E. Lombi, M.J. McLaughlin, Measurement of labile $\mathrm{Cu}$ in soils using stable isotope dilution and isotope ratio analysis by ICP-MS. Analytical and Bioanalytical Chemistry, 2004, 380, 789-797.

[15]. S. Sinaj, F. Machler, E. Frossard, Assessment of isotopically exchangeable zinc in polluted and nonpolluted soils. Soil Science Society of America Journal, 1999, 63, 1618-1625.

[16]. F. Degryse, N. Waegeneers, E. Smolders, Labile lead in polluted soils measured by stable isotope dilution. European Journal of Soil Science, 2007, 58, 1-7.

[17]. H-E. Gabler, A. Bahr, B. Mieke, Determination of the interchangeable heavy-metal fraction in soils by isotope dilution mass spectrometry. Fresenius Journal of Analytical Chemistry, 1999, 365, 409-414.

[18]. G. Welp, G.W. Brummer, Adsorption and solubility of ten metals in soil samples of different composition. Journal of Plant Nutrition and Soil Science - Zeitschrift fur Pflanzenernahrung und Bodekunde, 1999, 162, 155-161.

[19]. Cotter-Howells, J. and Thornton, I., Sources and pathways of environmental lead to children in a Derbyshire mining village. Environmental Geochemistry and Health, 1991, 13, 127-135. 
[20]. X. Li, I. Thornton, Chemical partitioning of trace and major elements in soils contaminated by mining and smelting activities. Applied Geochemistry, 2001, 16, 1693-1706.

[21]. N. Breward, Heavy metal contaminated soils associated with drained fenland in Lancashire, England, UK, revealed by BGS soil geochemical survey. Applied Geochemistry, 2003, 18, 16631670.

[22]. Phillips, A.D.M.,. Mossland reclamation and refuse disposal in the Manchester area in the nineteenth century. Industrial Archaeology Review, 1980, 4(3), 227-233.

[23]. L. Willies, K. Gregory, H. Parker, Millclose - The Mine That Drowned. 1989. Peak District Mines Historical Society Ltd. Scarthin Books, Cromford, England.

[24]. D.L. Rowell, Soil science: Methods and applications. 1994. Pearson Education Limited, Harlow.

[25]. S.M. Nelms, C.R. Quetetl, T. Prohaska, J. Vogl, P.D.P. Taylor, P.D.P., Evaluation of detector dead time calculation models for ICP-MS. Journal of Analytical Atomic Spectroscopy, 2001, 16, 333338.

[26]. J.R. Bacon, K.C. Jones, S.P. McGrath, A.E. Johnston, Isotopic character of lead deposited from the atmosphere at a grassland site in the United Kingdom since 1860. Environmental Science and Technology 1996, 30, 2511-2518.

[27]. P.E. Jensen, L.M. Ottosen, A.J. Pedersen, Speciation of $\mathrm{Pb}$ in industrially polluted soils. Water, Air and Soil Pollution, 2006, 170, 359-382.

[28]. J.M. Kaste, B.C. Bostick, A.J. Friedland, A.W. Schroth, T.G. Siccama, Fate and speciation of gasoline-derived lead in organic horizons of the Northeastern USA. Soil Science Society of America Journal, 2006, 70, 1688-1698.

[29]. M. McBride, S. Sauve, W. Hendershot, Solubility control of $\mathrm{Cu}, \mathrm{Zn}, \mathrm{Cd}$ and $\mathrm{Pb}$ in contaminated soils. European Journal of Soil Science, 1997, 48, 337-346.

[30]. N. Teutsch, Y. Erel, L. Halicz, A. Banin, Distribution of natural and anthropogenic lead in Mediterranean soils. Geochimica et Cosmochimica Acta, 2001, 65, 2853-2864. 
[31]. Grybos, M., Davranche, M., Gruau, G. and Petitjean, P., Is trace metal release in wetland soils controlled by organic matter mobility or Fe-oxyhydroxides reduction? Journal of Colloid and Interface Science, 2007, 314(2), 490-501.

[32]. Sauve, S., Manna, S., Turmel, M.-C., Roy, A.G. and Courchesne, F., Solid-solution partitioning of $\mathrm{Cd}, \mathrm{Cu}, \mathrm{Ni}, \mathrm{Pb}$ and $\mathrm{Zn}$ in the organic horizons of a forest soil. Environmental Science and Technology, 2003, 37, 5191-5196.

[33]. Terzano, R., Spagnuolo, M., Vekemans, B., de Nolf, W., Janssens, K., Falkenberg, G., Fiore, S. and Ruggiero, $\mathrm{P}$. Assessing the origin and fate of $\mathrm{Cr}, \mathrm{Ni}, \mathrm{Cu}, \mathrm{Zn}, \mathrm{Pb}$, and $\mathrm{V}$ in industrial polluted soil by combined microspectroscopic techniques and bulk extraction methods. Environmental Science \& Technology, 2007, 41(19), 6762-6769. 
List of Tables:

Table 1: Summary of the modified Tessier sequential extraction procedure (SEP).

Table 2: Selected chemical characteristics of study soils

Table 3: Labile $\mathrm{Pb}$ (E-value) as \% of total $\mathrm{Pb}$ concentration measured for four soils after 3 days post-spike equilibration period and suspended in $0.0005 \mathrm{M}$ EDTA electrolyte.

Table 4: Fractionation of $\mathrm{Pb}(\mathrm{F} 1$ - F5) measured by the modified Tessier sequential extraction procedure (SEP) 
Table 1: Summary of the modified Tessier sequential extraction procedure (SEP).

Fraction Reagents

F1: Exchangeable $\quad 0.5 \mathrm{M} \mathrm{MgCl}_{2}$

F2: Carbonate bound

$1 \mathrm{M} \mathrm{NaOAc}$ (adjusted to $\mathrm{pH} 5$ with HOAc)

F3: Fe/Mn oxide bound

$0.04 \mathrm{M} \mathrm{NH}_{2}$.OH.HCl

F4: Organic and sulphide bound

$0.02 \mathrm{M} \mathrm{HNO}_{3}$ and $\mathrm{H}_{2} \mathrm{O}_{2}, 3.2 \mathrm{M} \mathrm{NH}_{4} \mathrm{OAc}$.

F5: Residual

$\mathrm{HNO}_{3}, \mathrm{HF}, \mathrm{HClO}_{4}$. 
Table 2: Selected chemical characteristics of study soils

\begin{tabular}{llllll}
\hline & $\mathrm{pH}$ & $\begin{array}{l}\text { Loss on } \\
\text { ignition }(\%)\end{array}$ & $\begin{array}{l}\text { Available } \\
\text { phosphate } \\
\left(\mathrm{mg} \mathrm{kg}^{-1}\right)\end{array}$ & $\begin{array}{l}\text { Total } \\
\text { phosphate } \\
\left(\mathrm{mg} \mathrm{kg}^{-1}\right)\end{array}$ & $\begin{array}{l}\text { Total Pb } \\
\left(\mathrm{mg} \mathrm{kg}^{-1}\right)\end{array}$ \\
\hline $\begin{array}{l}\text { Arable } \\
\text { Fenland }\end{array}$ & 5.28 & 61.5 & 44.3 & 1920 & 364 \\
Sewage farm & 6.24 & 26.3 & 453 & 9540 & 525 \\
$\begin{array}{l}\text { Minespoil } \\
\text { Roadside }\end{array}$ & 7.65 & 13.6 & 9.70 & 832 & 13600 \\
\hline
\end{tabular}


Table 3: Labile $\mathrm{Pb}$ (E-value) as \% of total $\mathrm{Pb}$ concentration measured for four soils after 3 days post-spike equilibration period and suspended in 0.0005 M EDTA electrolyte.

\begin{tabular}{ll}
\hline Soil & $\% \mathrm{E}$ \\
\hline Arable fenland & 65.3 \\
Sewage farm & 13.5 \\
Roadside & 52.0 \\
Minespoil & 30.8 \\
\hline
\end{tabular}


Table 4: Fractionation of $\mathrm{Pb}(\mathrm{F} 1$ - F5) measured by the modified Tessier sequential extraction procedure (SEP)

\begin{tabular}{llllll}
\hline \multicolumn{5}{l}{ Fractionation of $\mathrm{Pb}(\%)$} & \\
& F1 & F2 & F3 & F4 & F5 \\
\hline Arable & 1.42 & 6.35 & 23.0 & 41.1 & 28.1 \\
Sewage & 0.00 & 0.19 & 1.84 & 0.00 & 98.0 \\
Minespoil & 1.75 & 19.4 & 33.4 & 20.3 & 25.2 \\
Roadside & 0.07 & 6.28 & 57.2 & 15.1 & 21.4 \\
\hline
\end{tabular}




\section{List of Figures:}

Figure 1. Lead isotopic characteristics of soils: isotopic ratios ${ }^{206} \mathrm{~Pb} /{ }^{207} \mathrm{~Pb}$ are plotted against ${ }^{206} \mathrm{~Pb} /{ }^{208} \mathrm{~Pb}$. Soils include (i) Sewage Farm $(\square)$, (ii) Arable Fenland $(\diamond)$, (iii) Minespoil $(\bigcirc)$ and (iv) Roadside $(\triangle)$ (Table 2). Common $\mathrm{Pb}$ sources are shown for reference: UK coal $(\diamond), \mathrm{UK} \mathrm{Pb}$ ore $(\boldsymbol{\square})$, and petrol-derived $\mathrm{Pb}(\boldsymbol{\Lambda})$. Error bars represent standard deviation of data but are omitted if smaller than the symbol size.

Figure 2: Labile $\mathrm{Pb}(\% \mathrm{E}$-value; Equation 1) as a proportion (\%) of total $\mathrm{Pb}$ plotted against EDTA concentration, with $+/-1 \%$ and $+/-10 \%$ errors applied to the estimation of the isotopic abundance of the isotope $\left({ }^{204} \mathrm{~Pb}\right)$ used to spike the soil suspensions. Error bars show standard error of three replicates.

Figure 3: Comparison of soil $\mathrm{Pb}$ fractions (\%), determined by sequential extraction, with isotopically exchangeable $\mathrm{Pb}(\%)$ in the Arable Fenland, Roadside, Minespoil and Sewage Farm soils.

Figure 4: Comparison of labile and non-labile lead isotopic signatures with known sources of lead contamination. Whole soil values are shown as a central point $(\mathbf{O})$ connected to Labile $(\bigcirc)$ and Non-labile $(\triangle) \mathrm{Pb}$ fractions. Common $\mathrm{Pb}$ sources are shown for reference: UK coal $(\diamond)$, $\mathrm{UK} \mathrm{Pb}$ ore $(\boldsymbol{\square})$, and petrol-derived $\mathrm{Pb}(\boldsymbol{\Delta})$. 


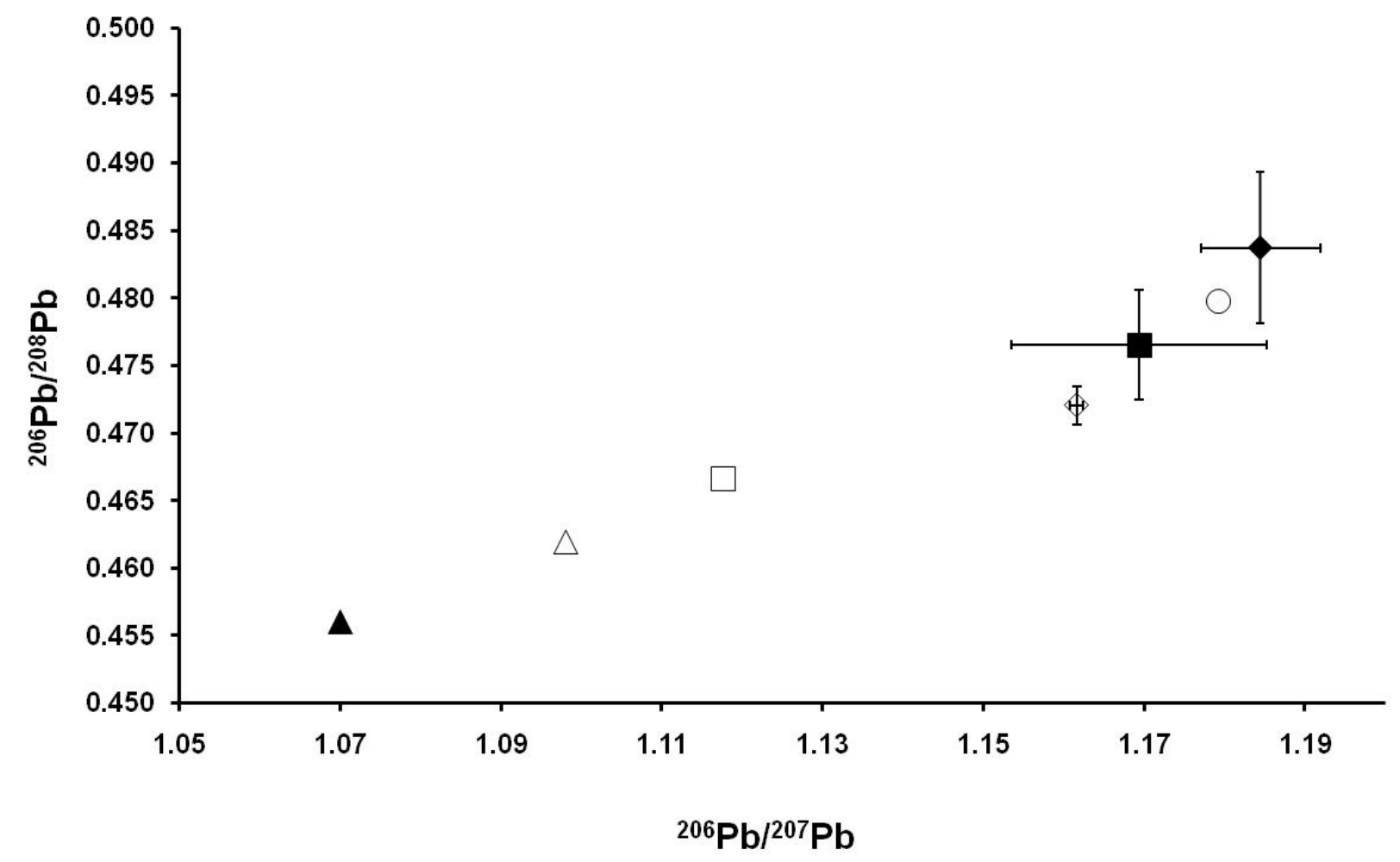

Figure 1. Lead isotopic characteristics of soils: isotopic ratios ${ }^{206} \mathrm{~Pb} /{ }^{207} \mathrm{~Pb}$ are plotted against ${ }^{206} \mathrm{~Pb} /{ }^{208} \mathrm{~Pb}$. Soils include (i) Sewage Farm $(\square)$, (ii) Arable Fenland $(\diamond)$, (iii) Minespoil $(\bigcirc)$ and (iv) Roadside $(\triangle)$ (Table 2). Common Pb sources are shown for reference: UK coal $(\diamond), \mathrm{UK} \mathrm{Pb}$ ore $(\boldsymbol{\square})$, and petrol-derived $\mathrm{Pb}(\boldsymbol{\Lambda})$. Error bars represent standard deviation of data but are omitted if smaller than the symbol size. 

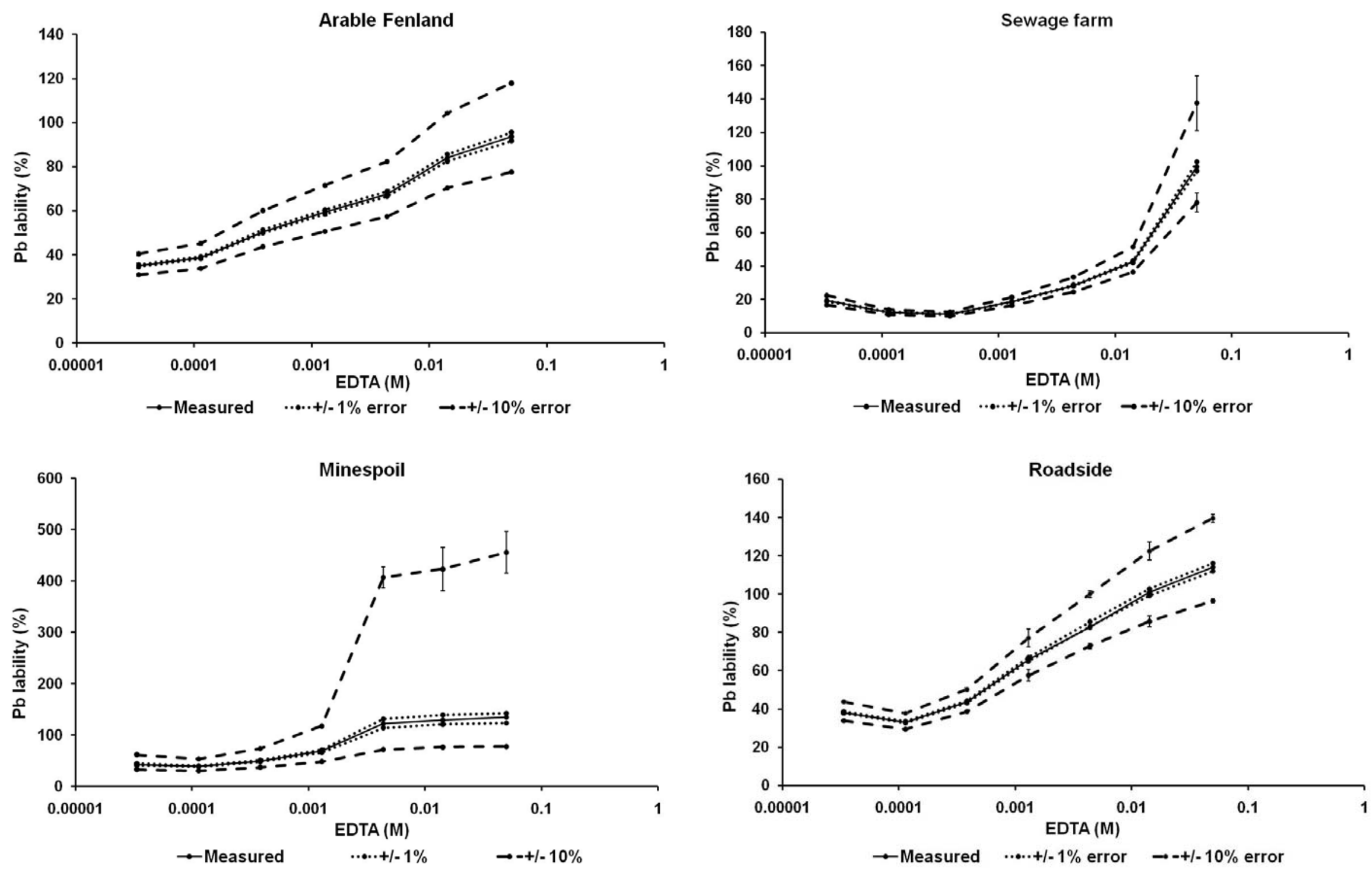

Figure 2: Labile $\mathrm{Pb}(\%$ E-value; Equation 1) as a proportion (\%) of total $\mathrm{Pb}$ plotted against EDTA concentration, with $+/-1 \%$ and $+/-10 \%$ errors applied to the estimation of the isotopic abundance of the isotope $\left({ }^{204} \mathrm{~Pb}\right)$ used to spike the soil suspensions. Error bars show standard error of three replicates. 

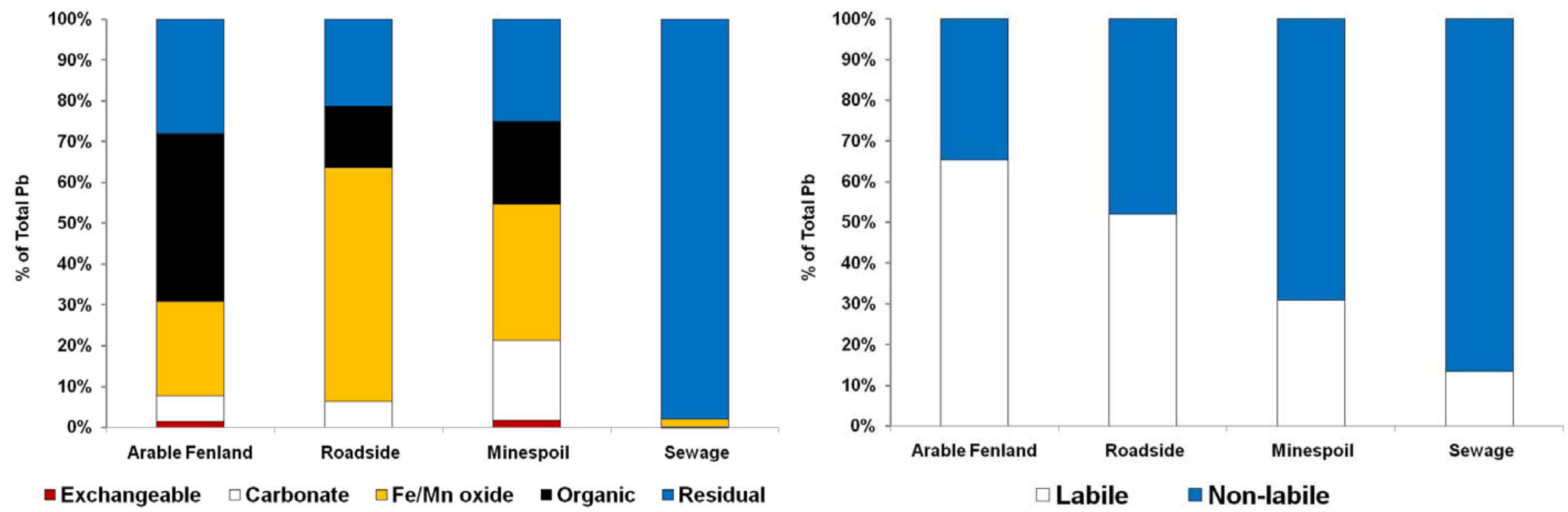

Figure 3: Comparison of soil $\mathrm{Pb}$ fractions (\%), determined by sequential extraction, with isotopically exchangeable Pb (\%) in the Arable Fenland, Roadside, Minespoil and Sewage Farm soils. 

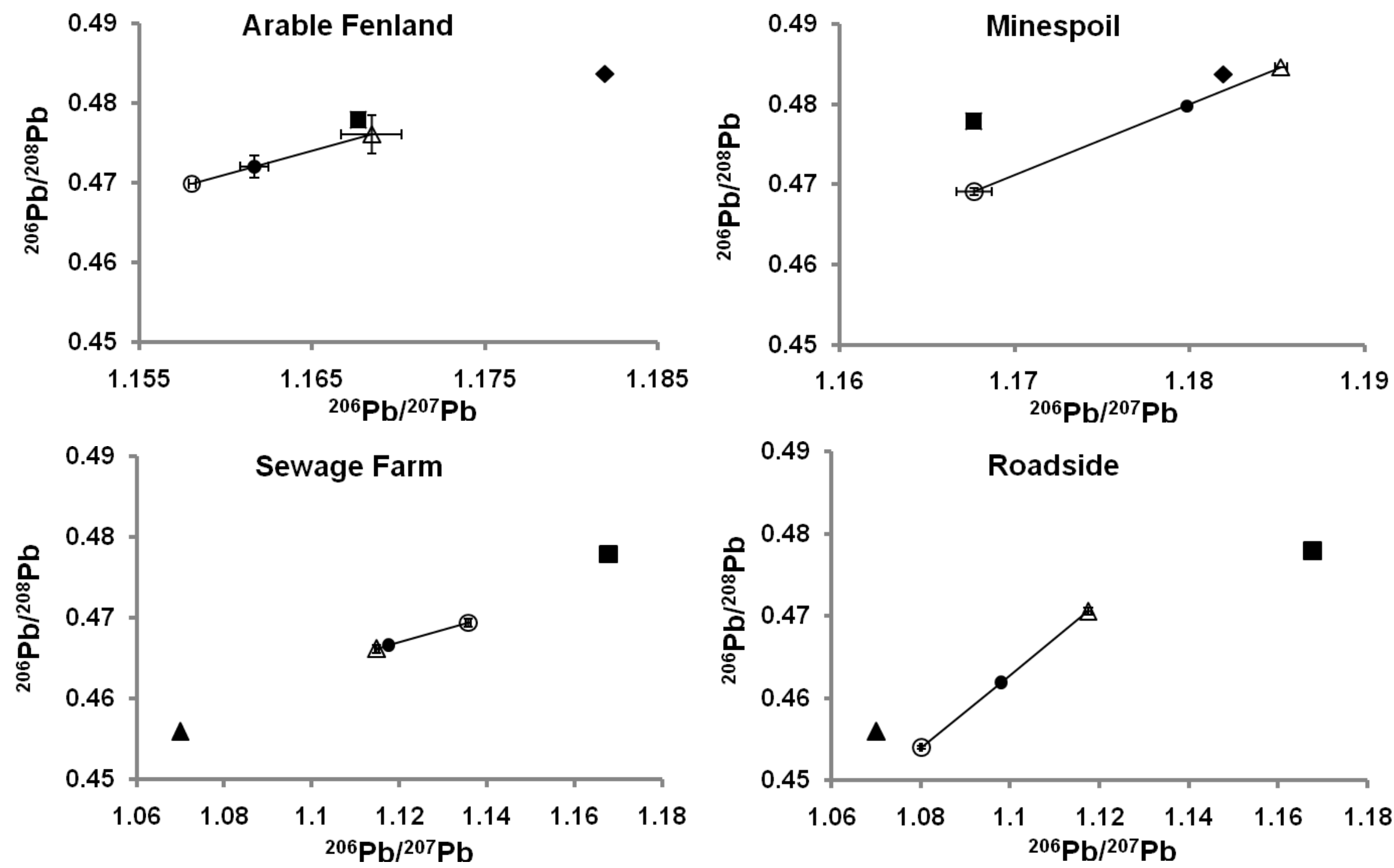

Figure 4: Comparison of labile and non-labile lead isotopic signatures with known sources of lead contamination. Whole soil values are shown as a central point $(\mathbf{O})$ connected to Labile $(\bigcirc)$ and Non-labile $(\triangle) \mathrm{Pb}$ fractions. Common $\mathrm{Pb}$ sources are shown for reference: $\mathrm{UK}$ coal $(\diamond)$, UK $\mathrm{Pb}$ ore $(\boldsymbol{\square})$, and petrol-derived $\mathrm{Pb}(\boldsymbol{\Delta})$. 